УДК 39

\title{
А.В. Игнатова
}

\section{О НЕПРЕХОДЯЩЕМ ЗНАЧЕНИИ ФОЛЬКЛОРА}

Рец на кн.: Строганов М.В. Исторические корни фольклорных жанров: Монография. М.: РГУ им. А.Н. Косыгина, 2019. 175 с.

DOI: $10.35634 / 2412-9534-2019-29-6-1091-1093$

Монография М.В. Строганова в равной степени заинтересует исследователей фольклора и изучающих его студентов. Исторические корни фольклорных жанров описываются ученым на фоне более широких и дискуссионных вопросов. Прежде всего он останавливается на терминологической неопределенности самого предмета изучения. Обратив внимание на то, что в науке традиционно под фольклором понимается устное народное поэтическое творчество, М.В. Строганов показывает семантическую неоднозначность определений «народное» и «поэтическое». Данные определения, с его точки зрения, являются неудовлетворительными, потому что категория «народ» исторически изменчива, социально неоднородна и отчуждена от исследователя, а категория «поэтическое» - факультативна и неабсолютна, ибо фольклор нельзя толковать исключительно как искусство слова: «Фольклор (...) не имеет сознательной установки на эстетическую функцию», он «может быть (...) понят только в системе этнографических изучений» (С. 8). Таким образом, оценив степень релевантности понятий и отдав предпочтение термину «фольклор», М.В. Строганов расширяет объект исследования по сравнению с тем, которым традиционно занимались фольклористы ХХ в. (Ю.М. Соколов, В.П. Аникин, Н.И. Кравцов), и признает необходимость обновления научного инструментария (например, призывает использовать краеведческий принцип в изучении фольклора, помещать предмет исследования «в один ряд с такими дисциплинами, как собственно краеведение, провинциаловедение, усадьбоведение, “культурные гнезда", областничество», изучать локальные тексты, ландшафтные образы «воображаемых сообществ» (С. 22). Фольклор, по мнению ученого, универсальная система, обеспечивавшая все культурные и бытовые нужды человека. Поэтому жанры фольклора можно соотносить с историей, медициной, агрономией, правом, метеорологией и другими сферами знания и общественных практик.

Определяя границы фольклорного текста, М.В. Строганов вслед за М.М. Бахтиным оперирует понятием первичные и вторичные жанры, показывает характер их взаимодействия, соотношение традиционализма и вариативности в фольклоре и литературе. Для ученого «фольклор - это не набор уже известных и устоявшихся жанров и приемов, а постоянное самовоспроизведение народного сознания в самых разных и неожиданных, непредсказуемых формах» С. 27). Например, рассматривая жанры современного фольклора, он выявляет в них архаичные элементы.

Основное содержание монографии М.В. Строганова посвящено описанию фольклорных жанров. Он строит его на основе исторической поэтики, выделяет три этапа в их развитии - дорефлекторный традиционализм, рефлекторный традиционализм, антитрадиционалистские тенденции нового времени. Наука каждый из этих этапов связывала с особым представлением о мире и человеке. Фольклорное сознание, считает ученый, на всех этапах своего развития характеризуется дорефлекторным традиционализмом. Поэтому динамика фольклорных жанров и их типология требует дополнительных объяснений. Это и является основной задачей исследователя. Приступая к изложению своей концепции, он пишет: «Наиболее близкой к нашим дальнейшим построениям является книга Е.М. Мелетинского, С.Ю. Неклюдова и Е.С. Новик об исторической поэтике фольклора. Но по целому ряду вопросов мы не согласны с этими исследователями, и, неизменно уважая их труд, мы полагаем, что и наше построение имеет право на существование» (С. 27-28).

Во второй главе монографии описывается фольклор доклассового общества. В поле зрения исследователя попадают малые жары (заговор, загадка, гадания, пословицы, поговорки, приметы), жанры календарной обрядности и сказки. Приступая к их изучению, М.В. Строганов характеризует мироотношение древнего человека, который был слаб перед природой и главным средством воздействия на нее считал слово. Заговор, загадка и гадание рассмотрены как жанры прямого словесного воздействия на природу; пословица, поговорка, примета - как жанры, словесно оформляющие законы природы. Ученый показывает историческую динамику этих жанров. Например, считая пословицы и 
поговорки сводом законов обычного права, он объясняет именно этим их актуальность для человека более поздних эпох, пополняющих арсенал этих жанров в период существования гражданского законодательства, которое действует не во всех людских сообществах. Вытеснение этих жанров в сферу семейных отношений, по его мнению, объясняется именно этим.

В календарной обрядности, как и в загадках, заговорах, гаданиях, ученый видит заклинательный смысл. Календарные обряды, по его мнению, реализуются формах тотемизма, анимизма, антропоморфизма; семейно-бытовые обряды «используют природоморфные формы, в которых человек уподобляется природным явлениям» (С. 50).

Отметив связь календарного обряда с мифом о вечном возвращении, М.В. Строганов характеризует его поэтику, опирающуюся на четыре составляющих элемента: почитание предков и поминальная еда, внимание к молодым и брачующимся, эротизм, ритуальный смех. Проанализировав все праздники аграрного календаря, ученый показал, что они строятся по одной модели: «Каждый раз (...) бог-солнце рождается и умирает под новым именем, от которого и берет название тот или иной праздник или один из его элементов (...). Каждый раз крестьяне встречают бога-солнце, радуются его приходу, величают его в специальных песнях, совершают вокруг него обрядовые действия, которые призваны усилить его мощь и усилить его брачный союз с землей, от которого зависит их благосостояние. И каждый раз, когда силы бога-солнца убывают, этот развенчанный, потерявший свое значение бог высмеивается и выбрасывается из обихода, ему устраиваются шутовские, снижающие похороны» С. 48). Говоря об исторической изменчивости жанров календарной обрядности, автор монографии отмечает редуцированность отдельных элементов, но утверждает, что похоронный и свадебный обряды сохраняют актуальность и в наши дни, хотя существенно видоизменяются. Видоизменение касается прежде всего связи составляющих обряд текстов с обрядовым действом: «...чем прочнее песня или приговор соединены с обрядовым действием, тем в большей степени они сохраняют связь с жанрами первичными, и, напротив, чем свободнее их положение внутри обряда, тем они более сближаются с жанрами вторичными» (С. 67). Хотя, по мысли исследователя, фольклорный текст потому и является фольклорным, что его жанр никогда не становится вторичным.

Рассматривая жанр доисторической сказки, М.В. Строганов утверждает, что на нее нельзя смотреть как на вымысел: для архаического человека в сказке воспроизводилась реальная история. Ученый описывает кумулятивную сказку, сказку о животных, волшебную и авантюрно-бытовую сказку. Исторические корни всех разновидностей этого жанра он находит в бытовых условиях догосударственного общества, осмысленных человеком мифологически. В завершении разговора ставится вопрос о причинах длительной сохранности сказки в народном сознании. Отвечая на него М.В. Строганов утверждает, что сверхъестественные силы, с которыми заключал договор человек в фольклорных жанрах, в сказке мыслятся как действующие лица, это позволяет сохранять интерес к ним современному человеку. Однако и сказка подвержена исторической деформации: фольклорные жанры, сформировавшиеся в догосударственный период, в настоящее время утрачивают свои функции, неизбежно эстетизируются.

В третьей главе монографии характеризуется фольклор государственного общества. Основным качеством мышления человека государственного периода русской жизни М.В. Строганов называет историзм и в формировании последнего выделяет два этапа: ранний (когда для человека было привлекательным героическое прошлое, противопоставляемое негероическому настоящему) и поздний (когда формировалось собственно-историческое мировосприятие). Ранний этап исторического мышления отразился в былинах и духовных стихах. Былину ученый определяет как форму государственной идеологии, опровергая ее устоявшееся в фольклористике восприятие как формы художественного творчества. Он отмечает историческую изменчивость былин: киевский и новгородский циклы былин наиболее откровенно отражают государственную точку зрения; семейные былины изображают устроение семьи как основы устроения государства. Особо следует подчеркнуть размышление М.В. Строганова над историзмом былин, где современное и частное событие видится в большой исторической перспективе, вписывается в эпическое время.

Духовные стихи представлены в монографии подкрепляющими государственную идеологию: их возникновение совпадает с христианизацией Руси и со становлением христианства как государственной религии.

Говоря о фольклорных жанрах более позднего периода (XIV-XVI вв.), М.В. Строганов связывает их с изменением исторического мышления человека, для которого ценным становится настоя- 
щее. Эта точка зрения отражена в исторической песне, народной балладе, духовных стихах «лирического» и «лиро-эпического» типа. В этих жанрах формируется личный, интимный характер переживания истории, ибо человек отображает осознание своего места в историческом процессе.

Важным поворотом исследовательской мысли является обращение к вопросу о том, как новые жанры возникают на обломках старых. Большая часть третьей главы монографии посвящена анализу этого процесса. Отметим описание фольклорного театра и необрядовой песни, представленных как результат разложения обрядовой сферы. М.В. Строганов исторически дифференцирует театральные формы в русской народной культуре, выделяя возникшие на обломках обряда и заимствованные. Рассматривая необрядовую песню, он показывает, как постепенно происходила эмансипация словесного текста от действия как конструкции речи.

Изучив динамику фольклорных жанров длительного исторического периода формирования государства и исторического мышления, ученый показал, как и в каких жанрах, возникших в это время, в последующие эпохи происходил процесс эстетизации.

Четвертая глава монографии посвящена фольклору индустриального и постиндустриального общества. Отмечая изменения в общественной жизни к началу XX в., ученый отмечает, что главным культурным приобретением в этот период стало формирование представления о самоценности личности. Это привело к антигосударственной направленности фольклора и отразилось в песенных жанpax (частушках, жестоких романсах), в фольклоре субкультур. Ученый показывает связь частушки со смеховой народной культурой и связь жестокого романса с народной балладой. Он отмечает в частушке осознание тождества автора и героя, что считает основанием для квалификации ее как лирического жанра в фольклоре. Жестокий романс рассматривается как стилизация (иногда многоступенчатая) народной песни и других разновидностей песенного жанра.

В монографии выделен фольклор разных субкультур (молодежной, детской, спортивных, эстрадных фанатов, фанатов анимэ и т.д.). Размышляя о его связи с традиционным фольклором М.В. Строганов пишет: «...фольклор тех или иных субкультур появляется одновременно с появлением этих субкультур и формируется на тех же самых условиях, на которых формируется и обычный общенациональный фольклор. Современные формы передачи информации как будто специально созданы для того, чтобы лишить эту информацию авторства и поддержать иллюзию безымянности ее. Иногда начинаешь думать, что безымянное переживание авторства свойственно не только архаической культуре, а всем этапам развития человечества, и авторская культура - это лишь частное исключение из общего правила безымянности» (С. 154). Этот вывод делает исследование ученого еще более актуальным, ибо позволяет архаические формы искусства напрямую типологически сопоставить с современными. А поскольку в монографии осмыслена историческая изменчивость поэтики, функций и места фольклорных жанров в отечественной культуре, их непреходящее значение предстает неопровержимым.

Поступила в редакцию 15.12.2019

Игнатова Анастасия Вячеславовна,

старший преподаватель

ФГБОУ ВО «Удмуртский государственный университет»

426034, Россия, г. Ижевск, ул. Университетская, 1 (корп. 2)

E-mail: ignatova.a.v@gmail.com
Ignatova A.V.,

Senior Lecturer,

Udmurt State University

Universitetskaya st., 1/2, Izhevsk, Russia, 426034

E-mail: ignatova.a.v@gmail.com 